\title{
An Improved Method for Soil DNA Extraction to Study the Microbial Assortment within Rhizospheric Region
}

\author{
Faria Fatima, ${ }^{1}$ Neelam Pathak, ${ }^{1}$ and Smita Rastogi Verma ${ }^{2}$ \\ ${ }^{1}$ Department of Biosciences, Integral University, Lucknow 226026, India \\ ${ }^{2}$ Department of Biotechnology, Delhi Technological University, Delhi 110042, India \\ Correspondence should be addressed to Smita Rastogi Verma; srsmitarastogi@gmail.com
}

Received 18 May 2014; Revised 10 August 2014; Accepted 19 August 2014; Published 15 September 2014

Academic Editor: Malayannan B. Subramaniam

Copyright (c) 2014 Faria Fatima et al. This is an open access article distributed under the Creative Commons Attribution License, which permits unrestricted use, distribution, and reproduction in any medium, provided the original work is properly cited.

\begin{abstract}
The need for identification of soil microbial community mainly depends on direct extraction of DNA from soil, a multifaceted environment that is a major pool for microbial genetic diversity. The soil DNA extraction procedures usually suffer from two major problems, namely, inappropriate rupturing of cells and contamination with humic substances. In the present study, five protocols for single type of rhizospheric soil were investigated and their comparison indicated that the inclusion of $120 \mathrm{mM}$ phosphate buffered saline (PBS) for washing and mannitol in the lysis buffer allowed the processing of soil sample in minimal time with no specific equipment requirement. Furthermore, DNA purity and yield were also improved, which allowed the exploitation of genetic potential of soil microbes within soil sample thereby facilitating the amplification of metagenomic DNA. The effectiveness of methods was analyzed using random amplification of polymorphic DNA. The banding patterns revealed that both the abundance and the composition of indigenous microbial community depend on the DNA recovery method.
\end{abstract}

\section{Introduction}

The biodiversity of microbes within soil is significant for the maintenance of healthy soil because these microbes are involved in many vital functions like crucial cycles of $\mathrm{C}$, $\mathrm{N}$, P, formation of soil, toxin removal, and so on. Previously, studies on the development of microbial communities required the isolation of these microbes from soil sample by culture dependent techniques followed by a series test for phenotypic evaluation and their identification. However, the microbial diversity studies conducted in soil have been biased essentially due to the unculturability of many microbes. Specific media, which are used to culture microbes, are selective in nature and only subpopulations of microbes from environment sample that will grow mainly depend on the particular conditions. It is reported that only $1 \%$ of microbes can be cultured in the laboratory using traditional culture techniques [1].

To study the microbial community, microbiologists have adopted culture-independent techniques. These techniques employ molecular biology based methods, in which soil extracted nucleic acid is subjected to PCR amplification [2]. These methods provide a unique insight into richness, composition, and structure of microbial community, that is, species richness and species evenness. The results thus rely not only on DNA extraction procedures but also on the factors affecting PCR amplification. Moreover, these culture-independent methods should address the problems like incomplete rupturing of cells and presence of soil organic substances, namely, fulvic and humic acid, the presence of which inhibit the activity of DNA polymerase, and interfere with the hybridization protocols [3]. Fractions like humic acids are usually the complex mixtures of related compounds (DNA) demonstrating a broad range spectrum of solubility and charge characteristics. Various physical and chemical treatments have been evaluated for cell rupture, which include shaking the sample in lysis buffers containing high concentration of sand, detergents or glass beads, inclusion of lysozyme [4]. Furthermore, purification of silica and other biogel columns has been reported to minimize the humic acid contamination. These procedures, however, make DNA isolation process expensive involving a large number of steps, 
which makes these procedures lengthy, time-consuming, and tedious. Therefore, an improved method is required for soil DNA extraction that would allow efficient rupturing of microbial cells and simultaneously decrease the contamination of organic materials (humic acid) in an easy and costeffective manner.

The analysis of microbial diversity in the soil DNA extracts is then based on ARDRA-amplified ribosomal DNA restriction analysis [5], DGGE-denaturing gradient gel electrophoresis, and " $T$ "-RFLP-Transfer restriction fragment length polymorphism [6]. However, random amplification of polymorphic DNA (RAPD) technique is preferred, as the above described techniques may not amplify fragments from all community members with equal effectiveness. Such approach thus offers significant advantage over just $1 \%$ of the microbial community accessible with standard, culturebased techniques. An additional advantage is that only small amount of soil sample is required for analyzing microbial diversity in a short span of time.

In the present study, four DNA extraction methods and a commercial Soil Master DNA extraction kit were used to extract DNA directly from soil and the effectiveness of these methods was estimated by RAPD analysis.

\section{Material and Methods}

2.1. DNA Extraction Methods. Five DNA extraction methods were evaluated in this study with respect to the quality and purity of extracted DNA using single type of rhizospheric soil. Three modified mannitol-based methods [7], polyethylene glycol (PEG/NaCl) method [8], and a soil DNA extraction kit were compared for obtaining a high recovery and DNA with good yield and purity. Isolated soil samples were isolated and immediately placed on dry ice, mixed, and then stored at $-20^{\circ} \mathrm{C}$ prior to DNA extraction.

2.1.1. DNA Extraction Using Polyethylene Glycol (PEG)/NaCl Method. One gram of soil sample was mixed with $10 \mathrm{~mL}$ of DNA extraction buffer (120 mM Na $\mathrm{HPO}_{4}$ ( $\mathrm{pH} 7.4$ ), $5 \% \operatorname{SDS}(\mathrm{w} / \mathrm{v})$ and $0.02 \mathrm{~g}$ PVPP) in centrifuge tubes and incubated for $1 \mathrm{~h}$ at $65^{\circ} \mathrm{C}$ with occasional stirring. The supernatant was collected after centrifugation at 8,000 rpm for $10 \mathrm{~min}$ at $4^{\circ} \mathrm{C}$ and mixed with half volume of PEG and 1 volume of $\mathrm{NaCl}$ and incubated at $4^{\circ} \mathrm{C}$ for overnight. Further, 1 volume of chloroform : isoamyl alcohol $(24: 1)$ was added and centrifuged at $12,000 \mathrm{rpm}$ for $10 \mathrm{~min}$ at $4^{\circ} \mathrm{C}$. The supernatant obtained was precipitated by addition of $1 / 10$ th volume of $3 \mathrm{M}$ sodium acetate ( $\mathrm{pH}$ 5.2) and 2 volumes of ethanol. Finally, the pellet was recovered by centrifugation at $12,000 \mathrm{rpm}$ at $4{ }^{\circ} \mathrm{C}$ and dissolved in $25 \mu \mathrm{L}$ TE buffer (Tris- $\mathrm{HCl} 10 \mathrm{mM}$ ( $\mathrm{pH} 7.8$ ); EDTA $1 \mathrm{mM}(\mathrm{pH} 8)$ ).

2.1.2. DNA Extraction Using Soil DNA Extraction Kit (Soil Master DNA Extraction Kit). DNA was extracted from soil sample (1 gm) according to the specifications of the supplier (EPICENTRE, Madison, WI, USA). The method involved direct cell lysis with prewarmed $5 \mathrm{~mL}$ solution $\mathrm{A}$ at $65^{\circ} \mathrm{C}$ and vortexing for $10 \mathrm{~min}$. This mixture was incubated for $15 \mathrm{~min}$ at $65^{\circ} \mathrm{C}$. The supernatants were collected after centrifugation at $8,000 \mathrm{rpm}$ at $4^{\circ} \mathrm{C}$ for $10 \mathrm{~min}$ and mixed with equal volume of solution $\mathrm{B}$ that led to precipitation. The steps were repeated two times when the color of supernatant changed to yellow. Finally the pellet was recovered by centrifugation at $12,000 \mathrm{rpm}$ for $10 \mathrm{~min}$ at $4^{\circ} \mathrm{C}$ and dissolved in $25 \mu \mathrm{L}$ TE buffer.

2.1.3. Modified Mannitol-Based Methods. One gram of soil sample was ground using liquid nitrogen. This was followed by addition of $5 \mathrm{~mL}$ of $120 \mathrm{mM}$ phosphate buffer saline $(\mathrm{pH}$ 7.4) and shaking at $150 \mathrm{rpm}$ for $10 \mathrm{~min}$ at $4^{\circ} \mathrm{C}$. The soil suspension was centrifuged at 7,000 rpm for $10 \mathrm{~min}$. The pellet was rewashed with PBS buffer and suspended in $10 \mathrm{~mL}$ of DNA extraction buffer containing $1 \mathrm{M}$ Tris- $\mathrm{HCl}$ ( $\mathrm{pH} 8.0), 5 \mathrm{M}$ $\mathrm{NaCl}, 0.5 \mathrm{M}$ EDTA (pH 8.0), 10\% CTAB, 10\% SDS, and $0.2 \mathrm{M}$ mannitol. The suspension was incubated for $1 \mathrm{~h}$ at $65^{\circ} \mathrm{C}$ with occasional stirring of $150 \mathrm{rpm}$ and subjected to three different treatments as indicated.

(i) DNA Extraction by Mannitol-Phosphate Buffer SalinePolyethylene Glycol/Sodium Chloride (Mannitol-PBS$\mathrm{PEG} / \mathrm{NaCl}$ ) Method. The soil suspension described above was centrifuged at $8,000 \mathrm{rpm}$ for $10 \mathrm{~min}$ at $4^{\circ} \mathrm{C}$ and the supernatant obtained was mixed with half volume of polyethylene glycol-8000 (50\%) (PEG) and 1 volume of $\mathrm{NaCl}$ and allowed to incubate at $4^{\circ} \mathrm{C}$ for overnight. The pellet was recovered by centrifugation at $12,000 \mathrm{rpm}$ at $4^{\circ} \mathrm{C}$ for $10 \mathrm{~min}$ and dissolved in $3 \mathrm{~mL}$ of TE buffer. The DNA sample was then purified by phenol: chloroform extraction. Finally DNA was precipitated by addition of $1 / 10$ th volume of $3 \mathrm{M}$ sodium acetate ( $\mathrm{pH}$ 5.2) and 2 volumes of ethanol. The pellet was recovered by centrifugation at $12,000 \mathrm{rpm}$ for $10 \mathrm{~min}$ at $4^{\circ} \mathrm{C}$ and dissolved in $25 \mu \mathrm{L}$ TE buffer (Tris- $\mathrm{HCl} 10 \mathrm{mM}(\mathrm{pH}$ 7.8); EDTA $1 \mathrm{mM}(\mathrm{pH} \mathrm{8)})$.

(ii) DNA Extraction by Mannitol-Phosphate Buffer SalinePhenol/Chloroform/Isoamyl Alcohol (Mannitol-PBS-PCI) Method. After centrifuging the soil suspension as previously described, the supernatant thus obtained was extracted with an equal volume of PCI by centrifugation at 12,000 rpm for $10 \mathrm{~min}$ at at $4^{\circ} \mathrm{C}$. Aqueous fraction was mixed with $1 / 10$ th volume of $3 \mathrm{M}$ sodium acetate ( $\mathrm{pH} 5.2)$ and 2 volumes of $70 \%$ chilled ethanol at $4^{\circ} \mathrm{C}$. Finally the pellet was recovered by centrifugation at $12,000 \mathrm{rpm}$ for $10 \mathrm{~min}$ at $65^{\circ} \mathrm{C}$ and dissolved in $25 \mu \mathrm{L}$ TE buffer (Tris- $\mathrm{HCl} 10 \mathrm{mM}$ (pH 7.8); EDTA $1 \mathrm{mM}$ ( $\mathrm{pH} 8))$.

(iii) DNA Extraction by Mannitol-Phosphate Buffer SalineCetrimide (Mannitol-PBS-CTAB) Method. After centrifugation of soil suspension, $50 \mu \mathrm{L}$ of $5 \mathrm{M} \mathrm{NaCl}$ and $50 \mu \mathrm{L}$ of $10 \%$ CTAB (cetrimide prepared in $0.7 \mathrm{M} \mathrm{NaCl}$ ) were added to the supernatant and incubated at $4^{\circ} \mathrm{C}$ for $15 \mathrm{~min}$. This was followed by addition of equal volume of PCI and centrifugation at $12,000 \mathrm{rpm}$ at $4^{\circ} \mathrm{C}$ overnight. Aqueous layer was allowed to precipitate overnight at $4^{\circ} \mathrm{C}$ with $1 / 10$ th volume of $3 \mathrm{M}$ sodium acetate ( $\mathrm{pH}$ 5.2) and 2 volumes of ethanol. Finally the pellet was recovered by centrifugation at $12,000 \mathrm{rpm}$ for $10 \mathrm{~min}$ at $65^{\circ} \mathrm{C}$ and dissolved in $25 \mu \mathrm{L}$ TE buffer (Tris- $\mathrm{HCl} 10 \mathrm{mM}(\mathrm{pH}$ 7.8); EDTA $1 \mathrm{mM}(\mathrm{pH} 8)$ ). 
2.2. DNA Yield and Purity. The DNA concentration of the soil sample was measured by examining the absorbance of the sample at $260 \mathrm{~nm}$ and the amount of DNA was calculated $\left(1.0 \mathrm{~A}_{260}\right.$ unit $=50 \mu \mathrm{g} / \mathrm{mL}$ of DNA $)$ [8]. The purity of the extracted DNA was determined by taking absorbance at 230, 260 , and $280 \mathrm{~nm}$. A pure sample of DNA has the $A_{260} / A_{280}$ ratio as 1.8 and the $\mathrm{A}_{260} / \mathrm{A}_{230}$ ratio as 2.0, whereas DNA preparation that is contaminated with protein will have an $\mathrm{A}_{260} / \mathrm{A}_{280}$ ratio lower than 1.8 [9].

2.3. PCR Amplification of Isolated Soil DNA Using 16S rRNA Primers for Bacterial Identification. Soil DNA was amplified by PCR using a PCR BIORAD Thermal Cycler (United Kingdom). Each $25 \mu \mathrm{L}$ PCR mixture contained $1 \mu \mathrm{L}(1: 10$ dilution) community DNA (10 ng-20 ng), $2.5 \mu \mathrm{L}$ PCR buffer (1X), $1 \mu \mathrm{L}$ of each deoxyribonucleoside triphosphate (dNTP) $(100 \mathrm{mM}), 1 \mu \mathrm{L}$ of forward and reverse primers $(0.5 \mu \mathrm{M})$, and $0.5 \mu \mathrm{L}$ Taq polymerase (3 U) (Fermentas). The $16 \mathrm{~S}$ rRNA regions were amplified by using $16 \mathrm{~S}$ rRNA primers, namely, (FP1) $5^{\prime}$-TGGGGAGCAAACAGGATTAG- $3^{\prime}$ and (RP1) $5^{\prime}-$ TAAGGTTCTTCGCTTGCTT- $3^{\prime}$. The amplification cycle consisted of an initial denaturation step of $30 \mathrm{~min}$ at $94^{\circ} \mathrm{C}$, followed by 35 cycles of $1 \mathrm{~min}$ at $94^{\circ} \mathrm{C}$ (denaturation), $1 \mathrm{~min}$ at $55^{\circ} \mathrm{C}$ (annealing), and $2 \mathrm{~min}$ at $72^{\circ} \mathrm{C}$ (extension), with a final extension step for $5 \mathrm{~min}$ at $72^{\circ} \mathrm{C}$. For visualizing PCR products, $5 \mu \mathrm{L}$ of the amplified product was electrophoresed on $1 \%$ agarose gel in 1X TAE buffer, stained with ethidium bromide (EtBr $0.5 \mu \mathrm{g} / \mathrm{mL}$ ) and analyzed by gel documentation system (BIORAD). Lambda DNA EcoRI/Hind-III double digest was used as a molecular size marker.

\subsection{PCR Amplification of Soil DNA Extract Using $18 \mathrm{~S}$ rRNA} Primers for Fungal Identification. Soil DNA was submitted for PCR amplification by using PCR BIORAD Thermal Cycler (United Kingdom). A region from $18 \mathrm{~S}$ rRNA gene was amplified using internal transcribed spacer (ITS) primers, namely, ITS 5: (5'-GGAAGTAAAAGTCGTAACAAGG-3') and ITS 4 ( $5^{\prime}$-TCCTCCGCTTATTGATATGC- $\left.3^{\prime}\right)$. Each $25 \mu \mathrm{L}$ reaction mixture contained $2 \mu \mathrm{L}$ soil DNA (10 ng$20 \mathrm{ng}$ ), $2.5 \mu \mathrm{L}$ PCR buffer (1X), $0.5 \mu \mathrm{L}$ deoxyribonucleoside triphosphate (dNTP mix) $(100 \mathrm{mM}), 0.5 \mu \mathrm{L}$ of forward and reverse primers $(0.2 \mu \mathrm{M}), 2 \mu \mathrm{L}$ of $\mathrm{MgCl}_{2}(25 \mathrm{mM})$, and $0.5 \mu \mathrm{L}$ Taq polymerase ( $3 \mathrm{U})$ (Fermentas). The amplification cycle consisted of an initial denaturation step of $5 \mathrm{~min}$ at $94^{\circ} \mathrm{C}$, followed by 35 cycles of $1 \mathrm{~min}$ at $94^{\circ} \mathrm{C}$ (denaturation), $1 \mathrm{~min}$ at $59^{\circ} \mathrm{C}$ (annealing), and $2 \mathrm{~min}$ at $72^{\circ} \mathrm{C}$ (extension), with a final extension step for $10 \mathrm{~min}$ at $72^{\circ} \mathrm{C}$.

2.5. Random Amplification of Polymorphic DNA (RAPD). To test the efficiency of soil DNA extraction methods, RAPD was performed on community DNA. Four decameric RAPD primers, namely, OPA 3, OPA 13, OPA 15, and OPA 20 (Operon Technologies), were investigated (Table 1). Random primers are short DNA fragments of arbitrary nucleotide sequence that can differentiate between genetically distinct individuals. The RAPD analysis was carried out through PCR amplification of total DNA. Amplification reactions were performed in a total volume of $25 \mu \mathrm{L}$ containing $2.5 \mu \mathrm{L}$
TABLE 1: Random primers used for RAPD analysis and their annealing temperature.

\begin{tabular}{lcc}
\hline Random primer & Primer sequences & Annealing temperature \\
\hline OPA 3 & $5^{\prime}$-AGTCAGCCAC & $32^{\circ} \mathrm{C}$ \\
OPA 13 & $5^{\prime}$-CAGCACCCAC & $32^{\circ} \mathrm{C}$ \\
OPA 15 & $5^{\prime}$-TTCCGAACCC & $32^{\circ} \mathrm{C}$ \\
OPA 20 & $5^{\prime}$-GTTGCGATCC & $32^{\circ} \mathrm{C}$ \\
\hline
\end{tabular}

PCR-buffer (10X), $2.5 \mu \mathrm{L}$ dNTP mix (2 mM), $1 \mu \mathrm{L}$ decameric primers (20 pmole), $2 \mu \mathrm{L}$ template (soil) DNA (100 ng), and $0.5 \mu \mathrm{L}$ Taq DNA polymerase $(3 \mathrm{U})$. The final volume was made up to $25 \mu \mathrm{L}$ using sterile distilled water. The amplification reaction was performed for 45 cycles, and each cycle comprised of $3 \mathrm{~min}$ at $94^{\circ} \mathrm{C}$ (denaturation), $1 \mathrm{~min}$ at $32^{\circ} \mathrm{C}$ (annealing), and $2 \mathrm{~min}$ at $72^{\circ} \mathrm{C}$ (extension), with a final extension at $72^{\circ} \mathrm{C}$ for $10 \mathrm{~min}$.

2.6. Analysis of PCR Products. For visualizing PCR products, $5 \mu \mathrm{L}$ of the amplified product was electrophoresed on $1 \%$ agarose gel in 1X TAE buffer, stained with ethidium bromide $(0.5 \mu \mathrm{g} / \mathrm{mL})$, and analyzed by Gel Documentation system (BIORAD). Lambda DNA EcoRI/Hind-III double digest was used as a molecular size marker.

\section{Results and Discussion}

For soil microbial analysis, it is essential to design protocols which yield high quality soil DNA of appropriate yield and purity for PCR amplifications. Besides, the selected methods for soil DNA extraction should be cost-effective and timesaving. Effectiveness of soil DNA extraction procedures may be influenced by various parameters such as incomplete cell lysis, DNA sorption to soil surfaces, extraction of humic contaminants, and DNA degradation. Thus, extraction of high molecular weight DNA, proper lysis of microbes, and inhibitor-free DNA are the major requirements for any protocol used for metagenomic study [10].

For cell lysis to be effective, mechanical treatment should be followed rather than chemical ones [11]. According to Frostegård et al. [4], proper grinding of sample ruptures the cell wall thereby releasing the cellular DNA from the inner compartment.

Soil DNA extraction procedures should therefore be free from PCR inhibitors or their concentration must be low enough so that they do not interfere with the enzymatic reactions. Usually organic matter is the major source of inhibitors that may be coextracted with the microbial DNA present with in the soil. Majorly, humic acids create considerable problem like interference in activity of DNA polymerase used for PCR reactions [12]. As humic acid contains the same charge and size characteristics like DNA, it exhibits absorbance at both 230 and at $260 \mathrm{~nm}$ and hence interferes in quantization of DNA. This characteristic can be used to find out the level of contamination of humic acid in an isolated DNA sample.

The present study involved comparison of five methods for isolation of soil DNA. Three methods having mannitol 
TABLE 2: Comparison of amount, purity of DNA, and humic acid contamination extracted from various isolation protocols.

\begin{tabular}{lccc}
\hline DNA extraction protocol & $\begin{array}{c}\text { Amount of } \\
\text { DNA } \\
(\mu \mathrm{g} / \mathrm{mL})\end{array}$ & $\mathrm{A}_{260 / 230}$ & $\mathrm{~A}_{260 / 280}$ \\
\hline $\begin{array}{l}\text { DNA extraction using PEG/NaCl } \\
\text { method [8] }\end{array}$ & 0.73 & 1.12 & 1.26 \\
$\begin{array}{l}\text { DNA extraction using } \\
\text { commercial soil DNA extraction }\end{array}$ & 0.79 & 1.21 & 1.32 \\
$\begin{array}{l}\text { kit (Soil Master DNA extraction } \\
\text { kit; EPICENTRE, Madison, WI, }\end{array}$ & & & \\
$\begin{array}{l}\text { USA) } \\
\text { DNA extraction by } \\
\text { mannitol-PBS-PEG/NaCl } \\
\text { method }\end{array}$ & 2.20 & 1.84 & 1.81 \\
$\begin{array}{l}\text { DNA extraction by } \\
\text { mannitol-PBS-PCI method }\end{array}$ & 2.36 & 1.93 & 1.84 \\
$\begin{array}{l}\text { DNA extraction by } \\
\text { mannitol-PBS-CTAB method }\end{array}$ & 2.67 & 2.07 & 1.85 \\
\hline
\end{tabular}

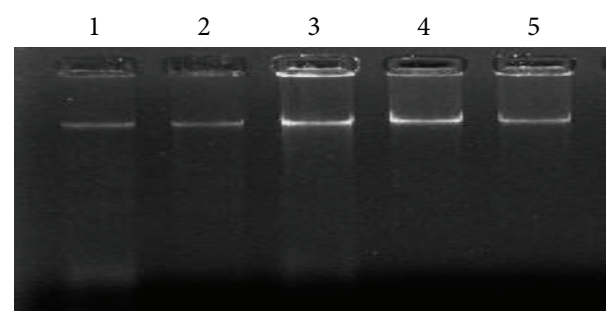

FIGURE 1: Visualization of soil DNA extracted by various methods. Lane 1: PEG/NaCl method without liquid nitrogen; lane 2: Soil Master DNA extraction kit; lane 3: mannitol-PBS-CTAB method; lane 4: mannitol-PBS-PCI method; lane 5: mannitol-PBS-PEG/NaCl method.

in their extraction buffer yielded an amount of DNA that was significantly higher than that obtained with the Soil Master DNA extraction kit and PEG/NaCl method (Table 2). Moreover, the purity of DNA isolated by modified mannitolbased methods was significantly higher as compared to other methods (Table 2). The addition of mannitol in the extraction buffer has already been reported to enhance the efficiency of soil DNA extraction [7]. Further modification of these methods by inclusion of $120 \mathrm{mM}$ phosphate buffered saline in the initial steps led to reduction in the level of organic contaminants such as humic acid at initial stages (Table 2). Soil Master DNA extraction kit and PEG/NaCl method with liquid nitrogen method consistently extracted DNA with higher $A_{260 / 230}$ and $A_{260 / 280}$ ratios, thereby indicating that the DNA was contaminated with humic acid-like compounds and proteins, respectively. $\mathrm{A}_{260 / 230}$ ratio of more than 2.0 was obtained with all the three mannitol-based methods, which was indicative of the fact that humic acid material very effectively reduced by these methods as compared to the other two methods.

The three modified mannitol-based methods led to the recovery of high molecular weight soil DNA (Figure 1). The recovery of high molecular weight DNA fraction is

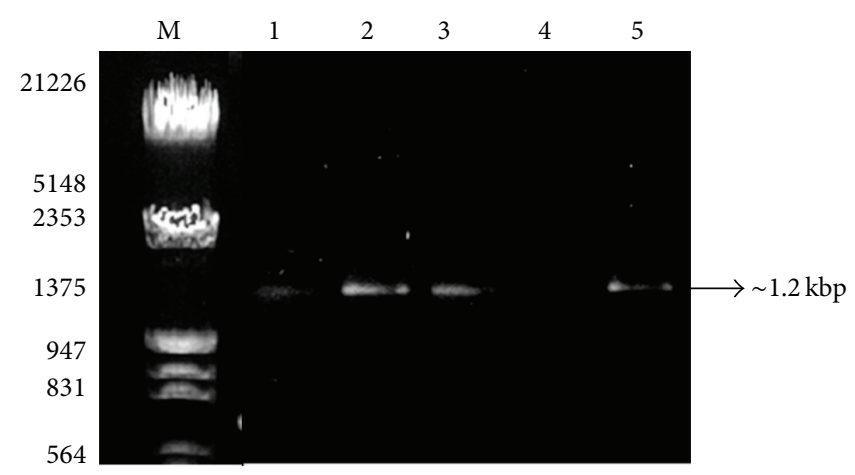

FIGURE 2: Visualization of PCR amplification products of soil DNA isolated by five different methods using $16 \mathrm{~S}$ rRNA by different methods. Lane M: $\lambda$ DNA EcoRI/Hind III double digest marker; lane 1: mannitol-PBS-PCI method; lane 2: Soil Master DNA extraction kit; lane 3: mannitol-PBS-CTAB method; lane 4: PEG/NaCl method without liquid nitrogen; lane 5: mannitol-PBS-PEG/NaCl method.

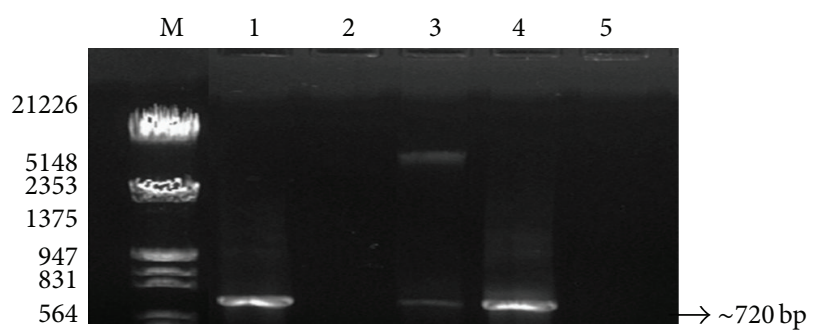

FIGURE 3: Visualization of PCR amplification products of soil DNA isolated by five different methods using $18 \mathrm{~S}$ rRNA by different methods. Lane M: $\lambda$ DNA EcoRI/Hind III double digest marker; lane 1: mannitol-PBS-CTAB method; lane 2: $\mathrm{PEG} / \mathrm{NaCl}$ method without liquid nitrogen; lane 3: mannitol-PBS-PEG/ $\mathrm{NaCl}$ method; lane 4: mannitol-PBS-PCI method; lane 5: Soil Master DNA extraction kit.

desirable for PCR assays used for microbial diversity analysis because the degraded DNA upholds the formation of chimera products. Moreover, these three modified mannitol-based methods were found to be more suited for PCR amplification. Nuclear rRNA genes have been useful in the molecular study of bacterial and fungal diversity [13].

High quality PCR amplicons with higher yields were observed in case of these three methods using 16S rRNAspecific and ITS-specific primers (ITS1/ITS4) for bacterial and fungal analysis, respectively. In each case, amplified products corresponded to expected sizes according to primers used. A single amplification product of $\sim 1.2 \mathrm{Kbp}$ for bacteria (Figure 2) and $\sim 720 \mathrm{bp}$ for fungi (Figure 3) was obtained. In case of the other two methods, namely, PEG/ $\mathrm{NaCl}$ with liquid nitrogen method and Soil Master DNA extraction kit, an acceptable level of DNA was amplified for bacterial community (Figure 2; lanes 1 and 4) but these two methods were not suitable for PCR amplification for fungal study (Figure 3; lanes 2 and 5). Usually, an enzyme DNA polymerase used in amplification processes requires contamination-free sites for proper functioning. Furthermore, better PCR amplification of soil DNA isolated by the three modified mannitol-based 


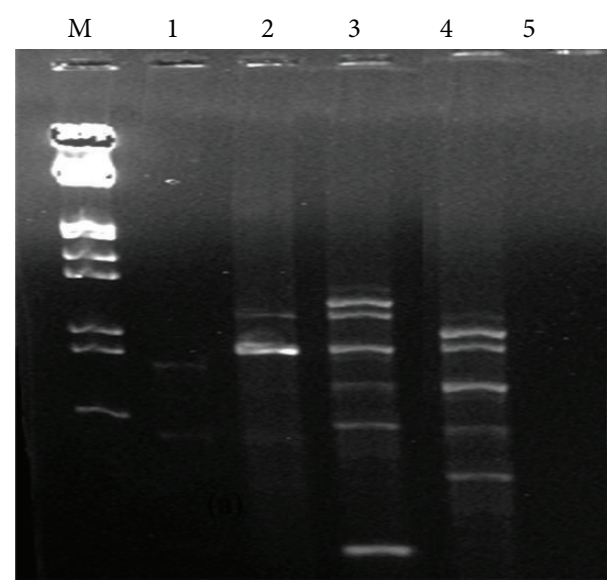

(a)

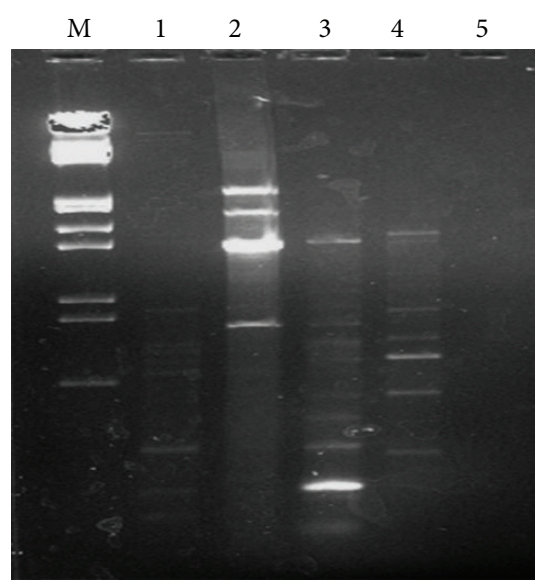

(b)

FIGURE 4: RAPD analysis of soil DNA samples isolated by five methods using random decameric primers. (a) OPA 3 and (b) OPA 13. Lane M: $\lambda$ DNA EcoRI/Hind III double digest marker; lane 1: Soil Master DNA extraction kit; lane 2: mannitol-PBS-CTAB method; lane 3: mannitolPBS-PEG/NaCl method; lane 4: mannitol-PBS-PCI method; lane 5: PEG/NaCl method without liquid nitrogen.

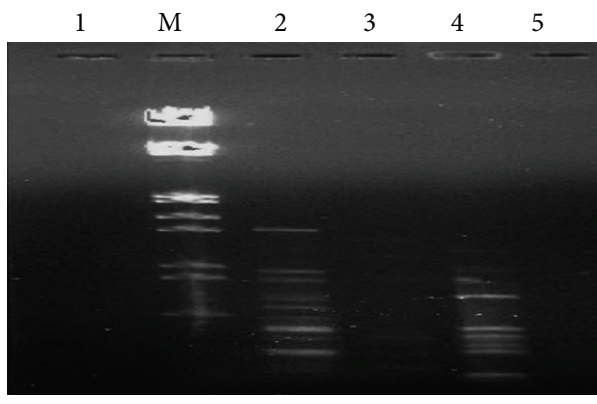

(a)

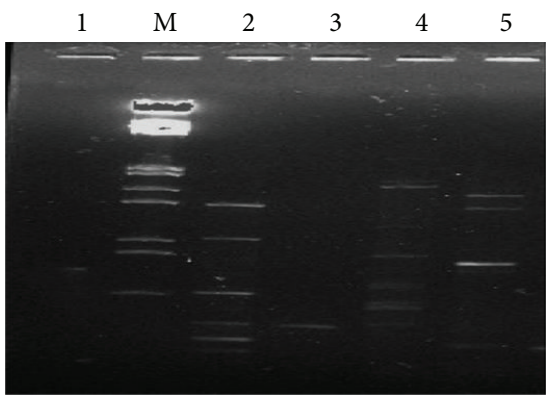

(b)

FIGURE 5: RAPD analysis of soil DNA samples isolated by five methods using random decameric primers. (a) OPA 15 and (b) OPA 20 . Lane M: $\lambda$ DNA EcoRI/Hind III double digest marker; lane 1: PEG/NaCl method without liquid nitrogen; lane 2: mannitol-PBS-CTAB method; lane 3: Soil Master DNA extraction kit; lane 4: mannitol-PBS-PCI method; lane 5: mannitol-PBS-PEG/NaCl method.

methods demonstrated better DNA yield and quality as compared to the other two methods. The study suggested that all three mannitol-based methods (PCI, PEG/NaCl, and CTAB) gave very good yield of DNA which was suitable for the amplification study in comparison with the other two methods which might be due to DNA-adhering substances like humic/fulvic acid having the same charge characteristics as those of DNA that were coprecipitated in the mannitoldevoid methods. Humic acid impurities may affect DNA hybridization efficiency too. The method in which mannitol with liquid nitrogen was used, showed high-quality chemical lysis as compared to other methods. It also proves that an addition of PBS bufffer and mannitol may play an important role in proper chemical lysis of the cells as compared to other chemicals like CTAB, SDS, EDTA, and so forth.

Thus, these methods proved to be a low-cost and practical alternative to accessing metagenomic content by addition of phosphate buffer (PBS) and mannitol within the soil sample.

Varying patterns of RAPD bands were found when soil community DNA samples were amplified using random primers. This indicated that the reported soil DNA extraction methods were quite feasible and reproducible for microbial diversity analysis (Figures 4 and 5). It was observed that the soil DNA isolated by protocols having mannitol was amplified easier than the methods using $\mathrm{PEG} / \mathrm{NaCl}$ and soil DNA extraction kit.

Thus, the procedure presented here proves to be an inexpensive procedure, which not only prevents the loss of DNA but also reduces the risk of contamination by laboratory DNA source. The protocols involved the usage of mannitol within the lysis buffer to isolate DNA from bacterial and fungal mycelia. The methods used in the present study exhibited sufficient quality and integrity to amplify the genetic regions, which provided a complete information and understanding of microbial biota. An inclusion of mannitol and sodium chloride promoted cell disruption and extracted humic acid and other organic contaminants, the presence of which would have otherwise inhibited PCR reaction. Hereby, it is demonstrated that a molecular approach using culture independent study can be used to complement more traditional methods used for the survey of microbial communities and provides 
an expanding toolbox, which helps the soil ecologists and taxonomists to explore microbial communities, which are still unidentified. The modified protocols can also contribute to in situ study of bacterial and fungal ecological processes.

\section{Conclusion}

In the present study, efficient soil DNA extraction procedures have been reported, which are simple and efficient and do not require elaborate instrumentation and yield good quality DNA suitable for the study of bacterial and fungal genes. It has been demonstrated that an additional step of using phosphate buffer saline with inclusion of mannitol was useful to achieve these objectives. The PCR amplification procedures involve several enzymatic reactions where the enzyme DNA polymerase requires sites, which should be contamination-free. It is suggested that the initial washing with PBS buffer led to removal of unwanted impurities such as humic acid present in the soil. Mannitol, having high salt nature, led the recovery of high molecular weight DNA. It probably interacted with cell wall resulting in cell disruption and extraction of humic acid near the beginning of the isolation procedure. Thus, these modified mannitolbased protocols help not only in improving the yield and quality of extracted soil DNA but also in exploitation of large-scale preparations which provide greater possibility for detecting genes present in low abundance within the soil environment. When combined with the methods developed for normalization of total metagenomic DNA, these modified protocols may offer an easy method for monitoring the population dynamics of the total microbial population in soils over time.

\section{Conflict of Interests}

The authors declare that there is no conflict of interests regarding the publication of this paper.

\section{Acknowledgments}

The financial support in the form of research grant from UP State Biodiversity Board, India, is highly acknowledged. The grant of UGC-Maulana Azad National Fellowship is gratefully acknowledged.

\section{References}

[1] J. R. Marchesi, T. Sato, A. J. Weightman et al., "Design and evaluation of useful bacterium-specific PCR primers that amplify genes coding for bacterial 16S rRNA," Applied and Environmental Microbiology, vol. 64, no. 6, pp. 795-799, 1998.

[2] C. Roh, F. Villatte, B.-G. Kim, and R. D. Schmid, "Comparative study of methods for extraction and purification of environmental DNA from soil and sludge samples," Applied Biochemistry and Biotechnology, vol. 134, no. 2, pp. 97-112, 2006.

[3] H. Luo, H. Qi, K. Xue, and H. Zhang, "A preliminary application of PCR-DGGE to study microbial diversity in soil," Acta Ecologica Sinica, vol. 23, pp. 1570-1575, 2003.
[4] Å. Frostegård, S. Courtois, V. Ramisse et al., "Quantification of bias related to the extraction of DNA directly from soils," Applied and Environmental Microbiology, vol. 65, no. 12, pp. 5409-5420, 1999.

[5] S. Weidner, W. Arnold, and A. Pühler, "Diversity of uncultured microorganisms associated with the seagrass Halophila stipulacea estimated by restriction fragment length polymorphism analysis of PCR-amplified 16S rRNA genes," Applied and Environmental Microbiology, vol. 62, no. 3, pp. 766-771, 1996.

[6] A. H. Goldstein and S. T. Liu, "Molecular cloning and regulation of a mineral phosphate solubilizing gene from Erwinia herbicola," Bio/Technology, vol. 5, no. 1, pp. 72-74, 1987.

[7] F. Fatima, I. Chaudhary, J. Ali, S. Rastogi, and N. Pathak, "Microbial DNA extraction from soil by different methods and its PCR amplification," Biochemical and Cellular Archives, vol. 11, no. 1, pp. 85-90, 2011.

[8] C. Yeates, M. R. Gillings, A. D. Davison, N. Altavilla, and D. A. Veal, "Methods for microbial DNA extraction from soil for PCR amplification," Biological Procedures Online, vol. 1, no. 1, pp. 4047, 1998.

[9] J. Sambrook and D. W. Russell, Molecular Cloning-A Laboratory Manual, Cold Spring Harbor Laboratory Press, Cold Spring Harbor, NY, USA, 2001.

[10] H. J. Gu, Y. Li, and W. Zhao, "Comparison of methods of DNA extraction from paddy soil," Journal of Jiangsu University, vol. 15, pp. 300-305, 2005.

[11] M. I. More, J. B. Herrick, M. C. Silva, W. C. Ghiorse, and E. L. Madsen, "Quantitative cell lysis of indigenous microorganisms and rapid extraction of microbial DNA from sediment," Applied and Environmental Microbiology, vol. 60, no. 5, pp. 1572-1580, 1994.

[12] S. Courtois, A. Frostegård, P. Göransson, G. Depret, P. Jeannin, and P. Simonet, "Quantification of bacterial subgroups in soil: comparison of DNA extracted directly from soil or from cells previously released by density gradient centrifugation," Environmental Microbiology, vol. 3, no. 7, pp. 431-439, 2001.

[13] T. R. Horton and T. D. Bruns, "The molecular revolution in ectomycorrhizal ecology: peeking into the black-box," Molecular Ecology, vol. 10, no. 8, pp. 1855-1871, 2001. 

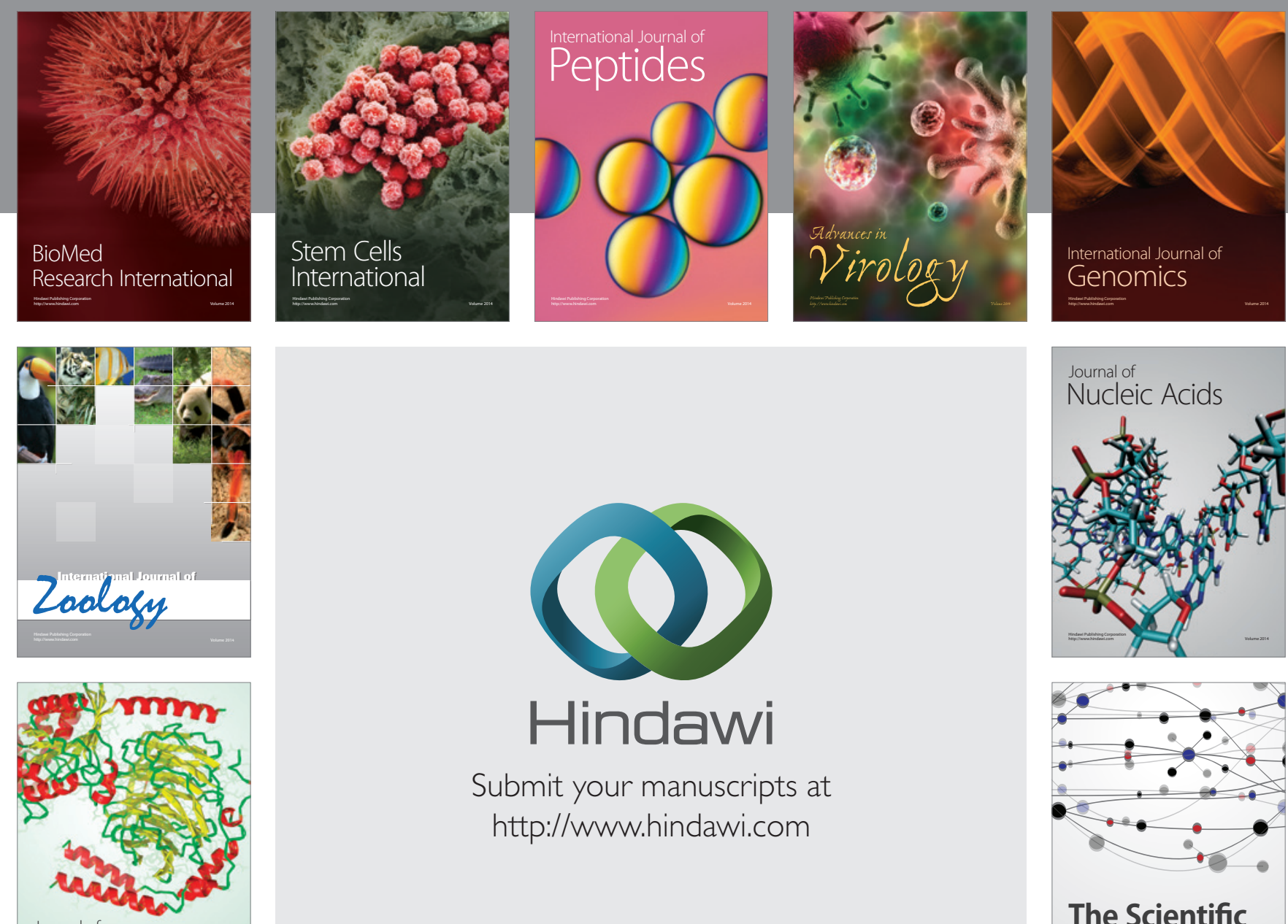

Submit your manuscripts at

http://www.hindawi.com

Journal of
Signal Transduction
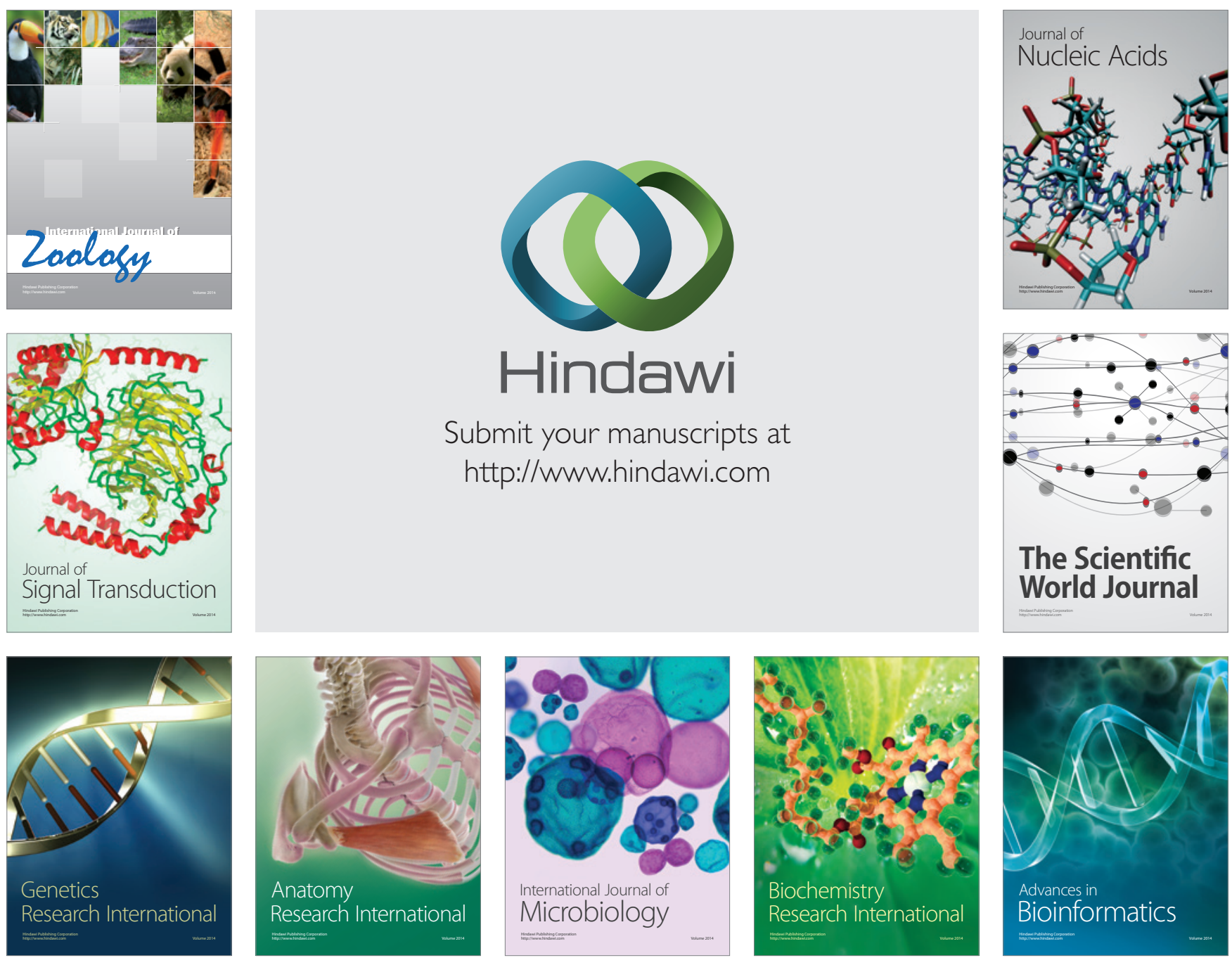

The Scientific World Journal
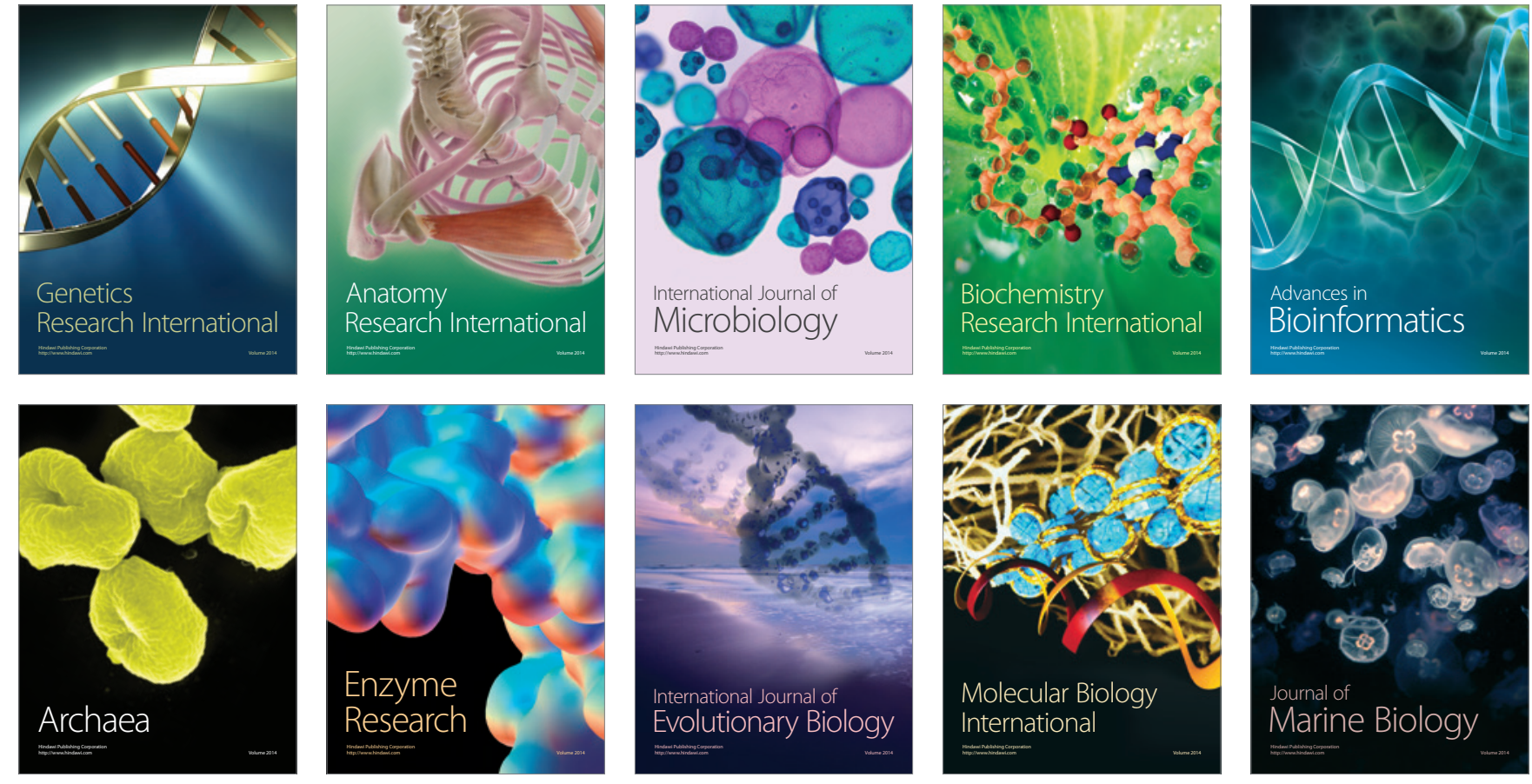